\title{
Alterations in lipid and carbohydrate metabolism attributable to cyclosporin $A$ in renal transplant recipients
}

\author{
K P G HARRIS， G I RUSSELL，S D PARVIN， P S VEITCH，J WALLS
}

\begin{abstract}
Thirteen non-diabetic renal transplant recipients had various aspects of carbohydrate and lipid metabolism studied before and after conversion from cyclosporin A to azathioprine. No patient had a glucose tolerance test result diagnostic of diabetes mellitus before conversion, and there was no change in fasting glucose or immunoreactive insulin values after conversion. There was, however, a fall in the area under the curve of the glucose tolerance test values after conversion. Furthermore, fasting serum cholesterol and triglyceride concentrations fell significantly after conversion. No change in the concentration of high density lipoprotein cholesterol was detected.

These findings suggest that cyclosporin $A$ is associated with an inferior lipid profile as compared with azathioprine, which may be important in patients with transplants given the drug long term.
\end{abstract}

\section{Introduction}

Cyclosporin A is now extensively used in organ transplantation and is both nephrotoxic and hepatotoxic. ${ }^{1}$ Recently it has been suggested that its use in pancreatic transplant recipients results in a deterioration in glucose metabolism as compared with azathioprine $^{2}$ but no other adverse metabolic effects have been noted.

\section{Present series}

\section{PATIENTS AND METHODS}

Thirteen non-diabetic cadaveric renal transplant recipients (mean age 39.6 years; range $21-64$ ) were studied three months after transplantation, when immunosuppression was with cyclosporin A (mean dose $8 \cdot 6$ (SEM $0.6) \mathrm{mg} / \mathrm{kg} / \mathrm{day}$ ), and again four months after transplantation, after successful conversion to azathioprine $(100-150 \mathrm{mg} / \mathrm{day})$. At both times the patients also received prednisolone $30 \mathrm{mg}$ on alternate days. Patients took normal diet, and when possible all other medication was left unchanged.

A $75 \mathrm{~g}$ oral glucose tolerance test was performed, and blood was obtained for estimation of fasting lipid and serum insulin values and for renal and hepatic function tests.

\section{RESULTS}

The trough plasma cyclosporin A concentration before conversion was 143 (SEM 30) $\mu \mathrm{g} / \mathrm{l}$. There was no change in body weight over the conversion period but there was a highly significant fall in serum cholesterol and triglyceride concentrations, although high density lipoprotein cholesterol did not change (table). The improvement in serum lipid values did not correlate with the cyclosporin A concentration but the improvement in triglyceride value did correlate with the improvement in creatinine con-

\footnotetext{
Departments of Nephrology and Surgery, Leicester General Hospital, Leicester LE5 4PW

K P G HARRIS, MA, MRCP, registrar in nephrology G I RUSSELL, MD, MRCP, senior registrar in nephrology S D PARVIN, MB, FRCSED, renal transplant fellow P S VEITCH, BMEDSCI, FRCS, senior lecturer in surgery J WALLS, MB, FRCP, consultant nephrologist

Correspondence to: Dr Walls, department of nephrology
}

Changes in carbohydrate and lipid values after conversion from cyclosporin $A$ to azathioprine in renal transplant recipients. Values are means (SEM in parentheses)

\begin{tabular}{|c|c|c|c|}
\hline & Before conversion & After conversion & p Value \\
\hline Serum creatinine $(\mu \mathrm{mol} / \mathrm{l})$ & $170(16 \cdot 6)$ & $131(11 \cdot 7)$ & $<0.005$ \\
\hline Fasting blood glucose $(\mathrm{mmol} / \mathrm{l})$ & $4.65(0.21)$ & $4 \cdot 6(0 \cdot 11)$ & \\
\hline $\begin{array}{l}\text { Area under curve of glucose } \\
\text { tolerance test values }\end{array}$ & $805(56)$ & $700(38)$ & $<0.05$ \\
\hline Fasting blood insulin (mU/1) & $13.7(1.86)$ & $14.4(1.98)$ & NS \\
\hline Serum cholesterol $(\mathrm{mmol} / \mathrm{l})$ & $7 \cdot 94(0 \cdot 4)$ & $6.45(0.37)$ & $<0.001$ \\
\hline $\begin{array}{l}\text { Serum high density lipoprotein } \\
\text { cholesterol }(\mathrm{mmol} / \mathrm{l})\end{array}$ & $0.94(0.07)$ & $0.89(0.06)$ & NS \\
\hline Serum triglyceride $(\mathrm{mmol} / \mathrm{l})$ & $2 \cdot 45(0 \cdot 2)$ & $1 \cdot 49(0 \cdot 14)$ & $<0.01$ \\
\hline
\end{tabular}

Conversion: SI to traditional units-Creatinine: 1 I $u$ mol $/=0.01 \mathrm{mg} / 100 \mathrm{ml}$. Glucose $1 \mathrm{mmol} / /=18 \mathrm{mg} / 100 \mathrm{ml}$. Cholesterol: $1 \mathrm{mmol} / \mathrm{l} \approx 38.6 \mathrm{mg} / 100 \mathrm{ml}$. Triglyceride: $1 \mathrm{mmol} / \mathrm{l} \approx 88.5 \mathrm{mg}$ $100 \mathrm{ml}$.

centration after conversion $(\mathrm{p}<0 \cdot 05)$. There was also a fall in the area under the curve of the glucose tolerance test values after conversion but no change in fasting glucose or insulin concentrations.

\section{Discussion}

The known reversible nephrotoxic potential of cyclosporin A was confirmed despite plasma cyclosporin concentrations being within the therapeutic range. Fasting glucose values did not change on conversion, which agrees with the European multicentre study comparing the two forms of immunosuppression. The area under the curve of the glucose tolerance test values, however, did fall on conversion. Prednisolone affects carbohydrate metabolism and, although the dose of prednisolone was unaltered, cyclosporin A has been shown to reduce prednisolone metabolism ${ }^{3}$ and may therefore potentiate its effects. Changes in renal function may also contribute to a reduction in the area under the curve by virtue of a change in insulin resistance, although no change in fasting insulin concentrations was detected.

Serum lipid abnormalities are common in uraemia and persist after transplantation, possibly contributing to the high incidence of atherosclerotic vascular disease in these patients. ${ }^{4}$ Uraemic patients have abnormal triglyceride handling with low high density lipoprotein cholesterol values, and an improvement in renal function would be expected to result in an improvement in triglyceride concentrations, as observed. Prednisolone also contributes to lipid abnormalities, although when low dose alternate day regimens are used with azathioprine, lipid values do not differ significantly from control values. ${ }^{5}$ If, however, cyclosporin A reduces prednisolone metabolism the effect of prednisolone may be enhanced.

Our results suggest that the use of cyclosporin $A$ is associated with an inferior lipid profile as compared with azathioprine, at least in the early postoperative period. To the extent that lipid abnormalities after transplantation may contribute to atherosclerotic vascular disease, this may be important when the drug is used long term.

\section{References}

1 Calne RY. Cyclosporin. Nephron 1980;26:57-63.

2 Gunnarsson R, Klintmalm G, Lundgren G, Wilczek H, Östman J, Groth CG. Deterioration in glucose metabolism in pancreatic transplant recipients given cyclosporin. Lancet 1983;ii:571-2. Ost L Effects of cyclosporin on prednisolone metabolism. Lancet 1984:i:451.

4 Chan MK, Varghese Z, Moorhead JF. Lipid abnormalities in uraemia dialysis and transplantation. Kidney

5 Turgan C, Russell GI, Baker F, Walls J. The effect of renal transplantation with minimal steroid regime on uraemic hypertriglyceridaemia. Qf Med 1984;53:271-7. 